\section{Analysis of quercetin and kaempferol levels in various phase of flowers Melastoma malabathricum L.}

\author{
Isnaini, ${ }^{1,2}$ Nur Permatasari, ${ }^{3}$ \\ Karyono Mintaroem, ${ }^{4}$ M. Aris Widodo ${ }^{3}$ \\ ${ }^{1}$ Faculty of Medicine, Brawijaya \\ University in Malang, East Java; \\ ${ }^{2}$ Department of Pharmacology and \\ Therapy, Faculty of Medicine, \\ University Mangkurat Banjarmasin, \\ South Kalimantan; ${ }^{3}$ Department of \\ Pharmacology Faculty of Medicine, \\ University of Brawijaya, Malang, East \\ Java; ${ }^{4}$ Department Pathology Faculty of \\ Medicine, University of Brawijaya, \\ Malang, East Java, Indonesia
}

\begin{abstract}
Melastoma malabathricum L. flowers are part of a plant that contains quercetin and kaempferol. Quercetin and kaempferol are useful for their antioxidant and anticancer properties. The flowering phase affects levels of quercetin and kaempferol. There are four phases of flower blooming: $1^{\text {st }}$ bud phase (K1), $2^{\text {nd }}$ bud phase (K2), $3^{\text {rd }}$ bud phase (K3), and flower bloom (M). It remains to be determined which phase of Melastoma malabathricum L. flowering shows the highest levels of quercetin and kaempferol. Quercetin and kaempferol levels were measured using HPLC MS/MS. The measured quercetin levels of K1, K2, $\mathrm{K} 3$, and $\mathrm{M}$ phases, respectively, were: 19.47 $\mu \mathrm{g} / \mathrm{g}, 17.78 \mu \mathrm{g} / \mathrm{g}, 31.2 \mu \mathrm{g} / \mathrm{g}$, and $94.32 \mu \mathrm{g} / \mathrm{g}$. Levels of kaempferol during K1, K2, K3, and $\mathrm{M}$, respectively, were: $140.99 \mu \mathrm{g} / \mathrm{g}$, $57.28 \mu \mathrm{g} / \mathrm{g}, 95.32 \mu \mathrm{g} / \mathrm{g}$, and $349.37 \mu \mathrm{g} / \mathrm{g}$.
\end{abstract}

\section{Introduction}

The use of natural ingredients for traditional medicine in Indonesia has been common for centuries. This is evidenced by the old manuscript on palm leaves Husodo (Java), Usada (Bali), Lontarak pabbura (South Sulawesi), documents on Fibre Primbon Charms, Fibre Blend Boreh Wulang nDalem and reliefs of Borobudur depicting people dispensing medicine (herbal medicine) with plants as a raw material. ${ }^{1}$

Melastoma malabathricum L. is one of the plants used as medicine. M. malabathricum L. is a plant that grows in the wild. Based on several studies, this plant can be used as an antidiarrheal, ${ }^{2,3}$ antioxidant, ${ }^{4,5}$ gastroprotective, ${ }^{6}$ for burns, ${ }^{7}$ antinociception, ${ }^{8,9}$ as an antibacterial, ${ }^{10,11}$ anticoagulant, ${ }^{12}$ antiinflammatory, ${ }^{9,13}$ for injuries, ${ }^{10}$ as an antivirus, ${ }^{14}$ and for cancer. $^{4,14}$

M. malabathricum L. contains saponins, tannins, flavonoids, steroids, and triterpenes. $^{3,9}$ Tannins contained in the leaves of $M$. malabathricum include malabathrins A, B C, D, E and F, nobotanin B, D, $\mathrm{G}, \mathrm{H}$ and $\mathrm{J}$, pterocarinin $\mathrm{C}$, casuarictin, strictinin, and pedunculagin. ${ }^{15}$ Flavonoids contained in $M$. malabathricum include $\alpha$ amyrin, ${ }^{12,16}$ quercitrin, ${ }^{12,16}$ quercetin, ${ }^{12,16}$ patriscabratin, ${ }^{16}$ auranamid, ${ }^{16}$ kaempferol3-O-(2",6"-in-Op-trans-kumarol)- $\beta$-glucoside, ${ }^{16}$ betulinik acid, ${ }^{12}$ kaempferol, ${ }^{16}$ and narigenin. ${ }^{16}$

Flowers of $M$. malabathricum $L$. are known to contain quercetin and kaempferol, which exert anticancer and antioxidant effects. Each phase has a different content of quercetin and kaempferol. The anticancer and antioxidant activity of M. malabathricum $L$. depends on the levels of quercetin and kaempferol of $M$. malabathricum L. Unknown levels of quercetin and kaempferol are in the phases of flowers that contain the highest quercetin and kaempferol. This research will examine the levels of quercetin and kaempferol in various phases of M. malabathricum L. flowers.

\section{Materials and Methods}

\section{Plant material}

Purple M. malabathricum L. flowers were used. M. malabathricum L. plant samples were obtained in the morning before 10:00 am from the area of Mount Kupang Banjarbaru South Kalimantan with 3028 '39.02 "S and 1140 51' 18.69" E. These plants were identified in the Laboratory of the University Lambung Mangkurat Banjarbaru South Kalimantan, Indonesia. Flowers of $M$. malabathricum L. are divided into four phases, namely bud 1 (K1), where flower buds have no petals on display, bud 2 (K2), where flower buds are starting to show petals, bud 3 (K3), where flower buds have already visible petals that are almost in bloom, and blooms (M), which is a flower that has bloomed completely, as shown in Figure 1. Other materials used were 95\% Quercetin (SigmaAldrich), 90\% kaempferol (Sigma Aldrich), methanol (Merck), acetonitrile (Merck), chloroform (Merck) ethyl acetate (Merck), and aquabidest (PT. Ikhapharmindo Putramas Pharmaceutical Industries).
Correspondence: Isnaini, Doctoral Program Student Interests Medical sciences Biomedical Graduate Program Faculty of Medicine, Brawijaya University in Malang, East Java, Indonesia, Departement of Pharmacology and Therapy Faculty of Medicine, University Mangkurat Banjarmasin, South Kalimantan, Indonesia Tel.: +0341.575790.

E-mail: isna_yusuf@yahoo.co.id

Key words: Flower Bud, Flower Bloom, HPLC, Quarcetin, kaempferol.

Contributions: the authors contributed equally.

Conflict of interest: the authors declare no potential conflict of interest.

Received for publication: 24 August 2016. Accepted for publication: 16 November 2016

This work is licensed under a Creative Commons Attribution-NonCommercial 4.0 International License (CC BY-NC 4.0).

C) Copyright Isnaini et al., 2018

Licensee PAGEPress srl, Italy

International Journal of Plant Biology 2018; 9:6846 doi:10.4081/pb.2018.6846

\section{Extraction}

$M$. malabathricum $L$. flowers were dried at room temperature, then mashed. The simplicia obtained was then extracted using the maceration method with $96 \%$ ethanol and dried with a dirotary evaporator, followed by freeze-drying.

\section{Determination of quercetin and kaempferol}

Quercetin and kaempferol levels were measured by HPLC, using a column with Hypersil Gold specifications $(50 \mathrm{~mm} \times 2.1$ $\mathrm{mm} \times 1.9 \mu \mathrm{m})$. The HPLC Equipment used was ACCELLA artificial type 1250 (Thermo Scientific) consisting of a vacuum degasser, quartenary pump, thermostatically controlled autosampler and a personal computer using the program x-calibur 2.1. Mobile phase A consisted of $0.1 \%$ formic acid in aquabidest, while phase B consisted of $0.1 \%$ formic acid in Acetonitrile. A linear gradient at a rate of $300 \mathrm{~mL} / \mathrm{min}$ with mobile-phase settings was used as follows: a) $0-0.6 \min 15 \% \mathrm{~B}$, (b) $2-3.5 \mathrm{~min} 100 \% \mathrm{~B}$, (c) $4.5 \min 15 \% \mathrm{~B}$. The injection volume in the LC was $2 \mu \mathrm{L}$. The column was controlled at $30^{\circ} \mathrm{C}$ and autosampler compartment was set at $10^{\circ} \mathrm{C}$.

Prior to analysis, each calibration standard was infused directly at a rate of 5 $\mathrm{mL} / \mathrm{min}$. The MS/MS Triple Q (quadrupole) 
mass spectrometer TSQ QUANTUM ACCESS MAX from Thermo Finnigan with an electrospray ionization (ESI) source was controlled by the software TSQ Tune operated in negative mode. Calibration standards 285 kaempferol with precursor ion $\mathrm{m} / \mathrm{z}$ obtained ion transitions of 239,229 , and $255 \mathrm{~m} / \mathrm{z}$, while standardization with quercetin 301 precursor ion $\mathrm{m} / \mathrm{z}$ obtained ion transitions of 179,245 , and $272 \mathrm{~m} / \mathrm{z}$.

Selected reaction monitoring (SRM) was performed using the following settings: $301>179 \mathrm{~m} / \mathrm{z}$ for quercetin and $285>229$ $\mathrm{m} / \mathrm{z}$ for kaempferol. ESI ionization conditions are as follows: spray voltage $3 \mathrm{kV}$; evaporation temperature of $270^{\circ} \mathrm{C}$; capillary temperature, $300^{\circ} \mathrm{C}$; a sheath gas nitrogen pressure of $40 \mathrm{psi}$; and an Aux gas pressure of 10 psi with argon gas. Chromatogram standards and samples were measured using LC-Quan software; results were then transferred to Excel software.

\section{Results and Discussion}

The chromatogram of each sample can be seen in Figures 2-6. The chromatograms show the average concentration of each sample (Table 1). Table 1 shows that the highest levels of quercetin and kaempferol are in phase $\mathrm{M}$, while the lowest levels of quercetin and kaempferol are found in K2.

Quercetin and kaempferol are compounds that act as antioxidants and also as anticancer compounds. The concentrations of quercetin and kaempferol affect its activity. Each phase of M. malabathricum $L$. flowering is characterized by different levels of quercetin and kaempferol. The results of the research show that the highest levels of quercetin and kaempferol are found in blooming flowers. This is in contrast with research by Janna et al. in $2006^{17}$ showing that levels of anthocyanins in M. malabathricum L. flowers are the highest in flower buds about to bloom and all petals. The research results on rose flower xhybrida conducted by Schmitzer et al. ${ }^{18}$ showed that the highest levels of quercetin are found in flower buds.

The anticancer effects of quercetin depend on its concentration. At a concentration of $1-20 \mu \mathrm{M}$, quercetin stimulates proliferation, while at concentrations of 50 $200 \mu \mathrm{M}$, the compound exerts pro-apoptosis effects, reducing the number of living cells. ${ }^{19}$ Kaempferol is well known for its cancer-fighting properties and has been linked with the prevention of breast cancer, ovarian cancer and prostate cancer. Kaempferol consumption also appears to reduce the risk of pancreatic and lung cancer. ${ }^{20}$ Kaempferol at a concentration of 1-10 $\mu \mathrm{M}$ stimulates proliferation by increasing the synthesis of DNA. At a concentration of 20-90 $\mu \mathrm{M}$, the compound inhibits cell

growth and DNA synthesis. ${ }^{21}$ Knowing the concentrations of quercetin and kaempferol allows us to predict their effects. Also, the

Table 1. Average levels of quercetin and kaempferol in various phases of flowering and fruiting.

\begin{tabular}{lccc} 
No & Phase & Average content $(\mathrm{Hg} / \mathrm{g})$ & \\
& & Quercetin & 140.99 \\
1 & K1 & 19.47 & 57.28 \\
\hline 2 & K2 & 17.78 & 95.32 \\
\hline 3 & K3 & 31.2 & 349.37 \\
\hline
\end{tabular}
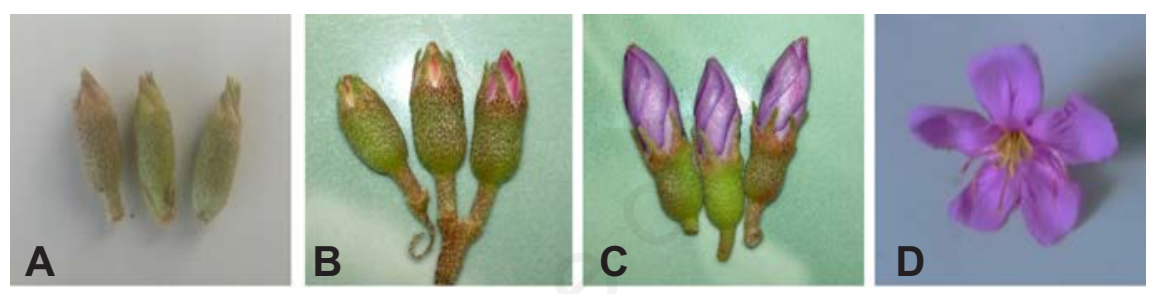

Figure 1. A) Bud 1, B) bud 2, C) bud 3 and D) blooms of M. malabathricum L.

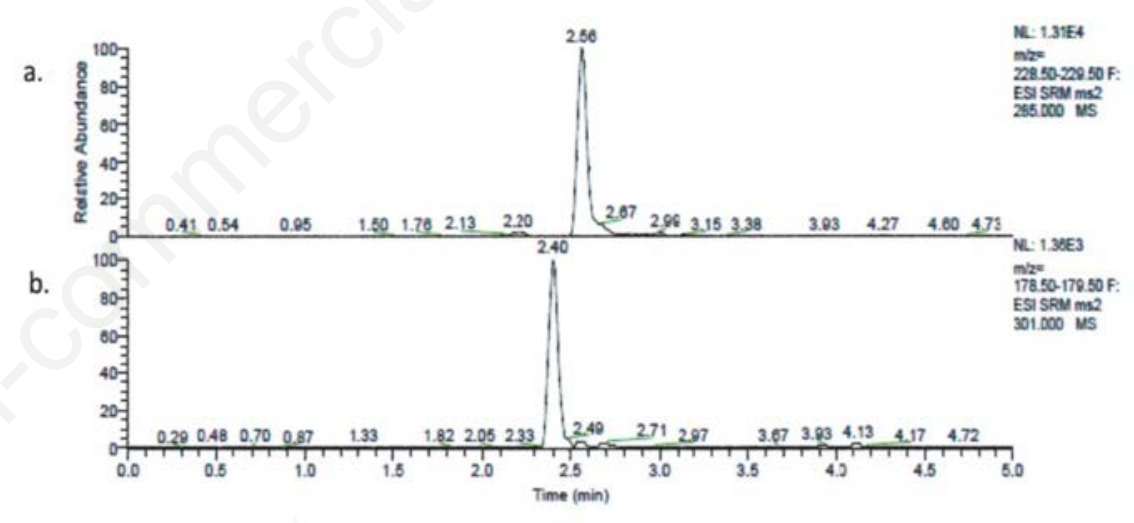

Figure 2. Results of HPLC buds 1 M. malabatbricum L. (K 1) (a) Quercetin, (b) kaempferol.

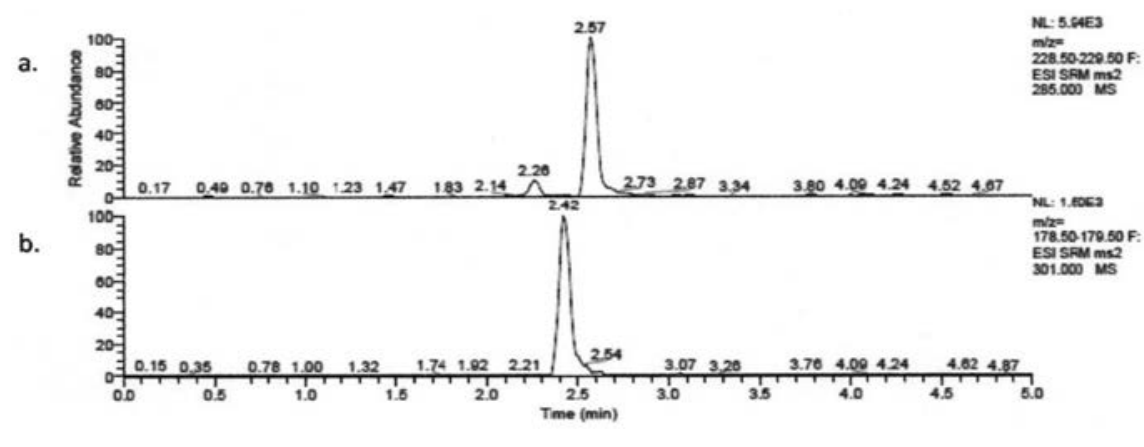

Figure 3. HPLC results for two M. malabathricum L. buds (K 2) (a) quercetin, (b) kaempferol. 
planning of flower harvest is a very important moment, because the flowering period determines the levels of quercetin and kaempferol.

\section{Conclusions}

The highest levels of quercetin and kaempferol are observed during the blos- a.

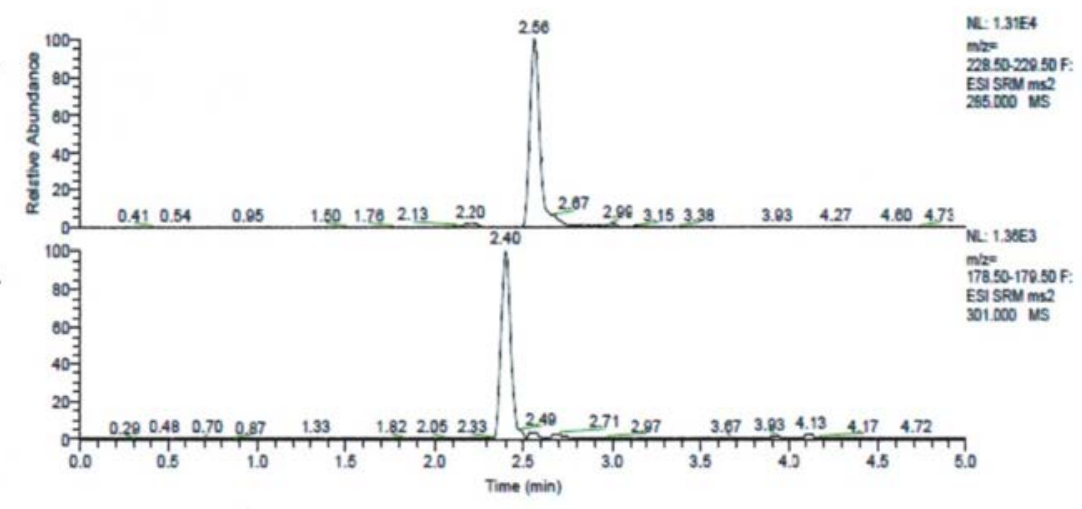

Figure 4. HPLC results for three M. malabathricum L. buds (K 3) (a) quercetin, (b) kaempferol.

a.

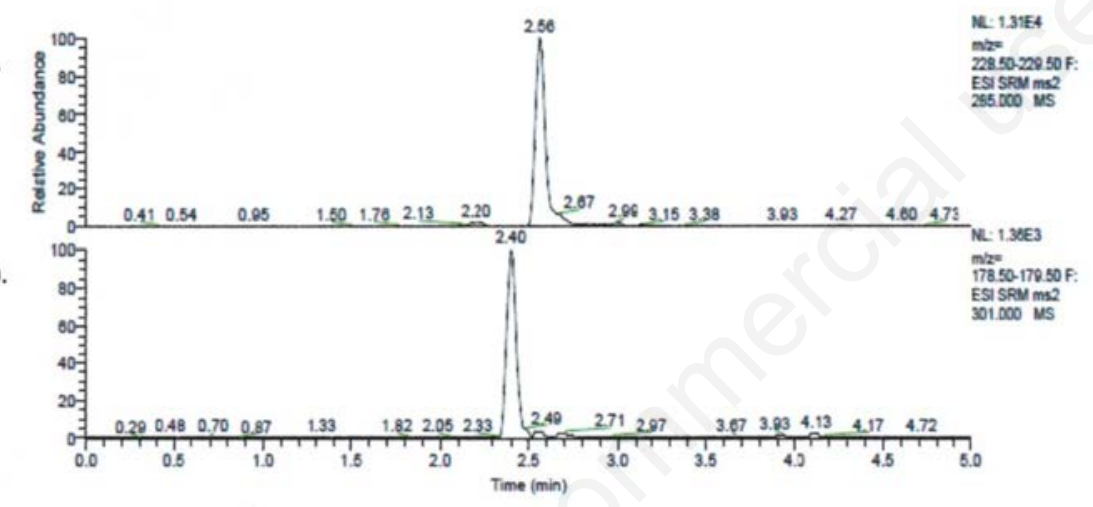

Figure 5. HPLC results for M. malabathricum L. flower bloom (M) (a) quercetin, (b) kaempferol.

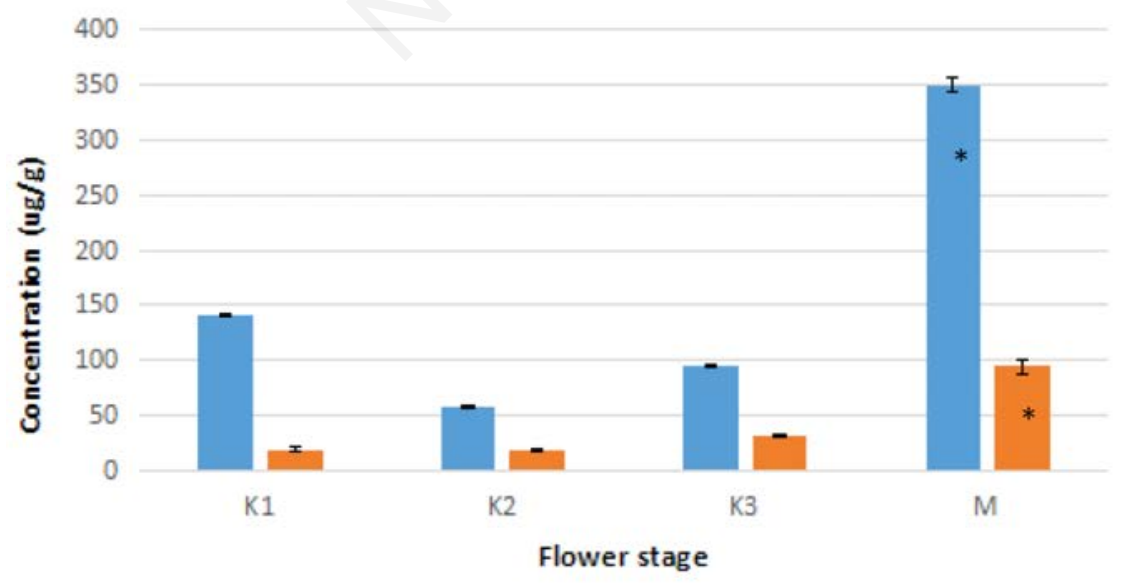

Kaempferol $\mathbf{E}$ Quercetin

Figure 6. Levels of quercetin and kaempferol in various phases of flowering. ${ }^{*} \mathbf{P}<0.05$ soming phase, with a quercetin concentration of $94.32 \mu \mathrm{g} / \mathrm{g}$ and kaempferol level of $349.37 \mu \mathrm{g} / \mathrm{g}$.

\section{References}

1. Sari L. Pemanfaatan Obat tradisional Dengan pertimbangan Manfaat Dan Keamanannya: Majalah ilmu Kefarmasian 2006;3:1-7.

2. Sunilson JAJ, Anandarajagopal K, Kumari A, Mohan S. Antidiarrhoeal activity of leaves of M. malabathricum Linn. Indian J Pharm Sci 2009;6:691-5.

3. Isnaini M, Bakhriansyah, Hendra W. Potensi buah karamunting (M. malabathricum 1.) Terhadap diare pada mencit jantan (mus musculus) yang diinduksi minyak jarak (oleum ricini). Laporan penelitian 2010.

4. Susanti D, Hasnah MS, Farediah A, et al. Antioxidant and cytotoxic flavonoids from the flowers of M. malabathricum L.. Abstract Food Chem 2007;3:710-6.

5. Chalise JP, Kalpana A, Nirmala G, et al. Antioxidant activity and polyphenol content in edible wild fruits from Nepal. Int J Food Sci Nutr 2010;4:425-32.

6. Hussain F, Mahmood AA, Suzita MN, et al. Gastroprotective effects of M. malabathricum aqueous leaf extract against ethanol-induced gastric ulcer in rats. Am J Biochem Biotechnol 2008;4:438-41.

7. Simanjuntak MR. Ekstraksi Dan Fraksinasi Komponen Ekstrak Daun Tumbuhan Senduduk (M. malabathricum L) Serta Pengujian Efek Sediaan Krim Terhadap Penyembuhan Luka Bakar. Fakultas Farmasi Universitas Sumatera Utara. Medan: Skripsi 2008.

8. Solomon MR, Somchit MN, Israf DA, et al. Antinociceptive effect of M. malabathricum ethanolic extract in mice. Fitoterapia 2004;7-8:667-72.

9. Zakaria ZA, RNS, Raden MN, et al. Antinociceptive and anti-inflammatory properties of M. malabathricum leaves choloform extract in eksperimental animals. J Pharmacol Toxicol 2006;4:33745.

10. Sunilson AJ, Jisha J, John T, et al. Antibacterial and wound healing activities of M. malabathricum Linn. Afr J Infect Dis 2008;2:68-73.

11. Choudhury MD, Deepa N, Anupam DT. Antimicrobial activity of M. malabathricum L. J Biol Environ Sci 2011;1:76-8

12. Manicam C, Janna OA, Eusni RMT, et al. In vitro anticoagulant activities of $\mathrm{M}$. malabathricum Linn. aqueous leaf extract: a preliminary novel finding. J 
Med Plants Res 2010;41:1464-72.

13. Mazura MP, Susanti D, Rasadah MA. Anti-inflammatory action of components from M. malabathricum. Pharm Biol 2007;5:372-5.

14. Nazlina I, Norha S, Noor AW, Ahmad IB. Cytotoxicity and antiviral activity of M. malabathricum extracts. Malays Appl Biol 2008;2:53-5.

15. Yoshida T, Fumihisa N, Kumi H, et al. Tannins and related polyphenols of melastomaceae plants V. three new compleks tannins from melastoma malabathricum L. Chem. Pharm Bull 1992;7:1727-32.
16. Susanti D, Hasnah MS, Farediah A, Rasadah MA. Bioactive constituents from the leaves of M. malabathricum L. J Ilmiah Farmasi 2008;1:1-8.

17. Janna OA, Khairul A, Maziah M, Mohd Y. Flower pigment analysis of Melastoma malabathricum. Afr J Biotechnol 2006;2:170-4.

18. Schmitzer V, Robert V, Gregor O, Franci S. Changes in the phenolic concentration during flower development of rose KORcrisett. J Am Soc Hort Sci 2009;134:491-6.

19. Jaganathan SV, Mandal M. Antiproliferative effects of honey and of its polyphenols: a review. J Biomed Biotechnol 2009;1-113.

20. Dar RA, Gowhar AN, Israr UH, Ahamad MH. Electrochemical behavior of kaempferol and its determination in presence of quercetin employing multiwalled carbon nanotube modified carbon paste electrode. Anal Chem Res 2016;7:1-8.

21. Wang C, Kurzer MS. Phytoestrogen concentration determines effect on DNA synthesis in human breast cancer cells. Nutr Cancer 1997;28:236-47. 